Jurnal Ilmu Ilmu Agribisnis: Journal of Agribusiness Science, 9(2), Mei 2021

\title{
ANALISIS PENDAPATAN USAHATANI DAN FAKTOR-FAKTOR YANG MEMPENGARUHI PRODUKSI CABAI MERAH DI DESA TRIMULYO KECAMATAN TEGINENENG KABUPATEN PESAWARAN
}

\author{
(Analysis Income Farming and Factors Production of Red Chili in Trimulyo, Tegineneng \\ Pesawaran Regency)
}

Intan Sayna Rahmadanti, Wan Abbas Zakaria, Lina Marlina

Jurusan Agribisnis, Fakultas Pertanian, Universitas Lampung, Jl. Prof. Dr. Soemantri Brojonegoro No.1 Bandar Lampung 35145, e-mail: wanabas.zakaria@fp.unila.ac.id

\begin{abstract}
This research aims to analyze income farming and factors affecting production of red chili in Trimulyo Tegineneng Pesawaran Regency. This research uses a survey method. Location of this research is chosen purposively in Trimulyo. The respondents are 60 red chili farmers taken by using a simple random sampling method. The income farming is determined using revenue cost ratio, while factors of production are analyzed by using Cobb Douglass. The results of the study showed that the income per hectare over cash costs obtained by farmers was IDR34,416,181.43 with $R / C$ of 2.18 and income per hectare over total costs amounted to IDR24,520,886.39 with $R / C$ of 1.63. Factors affecting production of red chili are land, seeds, KNO3 fertilizer, and pesticide. The $R / C$ value that is greater than one means that red chili farming in Trimulyo Village Tegineneng Subdistrict Pesawaran Regency is profitable and feasible to be cultivated.
\end{abstract}

Key words: income, production, red chili

\section{PENDAHULUAN}

Indonesia dikenal sebagai negara yang memiliki potensi pertanian yang sangat baik, sehingga Indonesia disebut sebagai negara agraris yang berarti negara yang mengandalkan sektor pertanian.Hortikultura merupakan sub sektor yang bergandengan dengan tanaman pangan serta bergabung dalam satu bidang, sehingga penanganannya terprogram tidak jauh dari tanaman pangan yang saling berhubungan erat. Tanaman hortikultura sendiri terbagi menjadi beberapa komoditas yaitu buah-buahan, sayuran, tanaman hias, dan tanaman obat (Supriadi dan Roedjinandari 2017).

Cabai merah merupakan komoditas sayuran yang memiliki nilai ekonomi tinggi dan banyak diusahakan oleh petani di dataran rendah sampai dataran tinggi.Penanamannya dilakukan di lahan sawah maupun lahan kering.Komoditas cabai merah merupakan salah satu komoditas strategis dan unggulan nasional di Indonesia(Moekasan Prabaningrum dan Yoga 2014).

Permasalahan khusus pada komoditas cabai merah di Indonesia secara global meliputi pasokan belum stabil sepanjang tahun, masih terdapat cabai merah impor olahan di pasar, adanya disparitas harga cabai merah yang tinggi, daya saing komoditas cabai merah yang rendah, angka ekspor komoditas cabai merah yang masih rendah, dan konsumsi utama cabai merah di Indonesia masih lebih disukai dalam bentuk segar dibanding produk olahan (Direktorat Jenderal Hortikultura 2017).

Provinsi Lampung merupakan salah satu wilayah yang memiliki potensi dalam menghasilkan cabai merah di Indonesia. Menurut BPS (2018), salah satu sentra cabai merah di Provinsi Lampung adalah Kabupaten Pesawaran dengan luas panen dan produksi yaitu1.256 ha dan 12.975 ton serta tingkat produktivitas 10,33 ton/hadengan Kecamatan Tegineneng sebagai sentra produksi.

Berdasarkan informasi, desa yang menjadi sentra usahatani cabai merah di Kecamatan Tegineneng yaitu Desa Trimulyo.Desa tersebut mayoritas penduduknya bermata pencaharian sebagai petani, terkhusus usahatani cabai merah.

Produktivitas cabai merah di Desa Trimulyo tahun 2018 masih tergolong rendah yaitu 11 ton/ha. Menurut Tim Bina Karya Tani (2008), usahatani cabai merah yang dikelola dengan baik akan mendapatkan hasil produktivitas sebesar 20 ton/ha dengan jarak antar tanaman $60 \times 70 \mathrm{~cm}$. Tingkat produksi cabai merah di Kabupaten Pesawaran pada tahun 2013-2017 tidak selalu mengalami peningkatan. Hal ini diduga kurangnya ketersediaan pupuk dan varietas unggul, teknik 
bercocok tanam dan pengendalian hama yang masih kurang memadai, rendahnya tingkat kesuburan tanah, penggunaan alat pertanian yang masih tradisional, modal yang dimiliki sangat terbatas, serta tingginya biaya produksi usahatani cabai merah (Dinas Pertanian Kabupaten Pesawaran 2018).

Berdasarkan uraian latar belakang masalah, tampak bahwa peningkatan produksi cabai merah sangat diperlukan.Oleh sebab itu, perlu diketahui tingkat pendapatan usahatani dan faktor-faktor yang mempengaruhi produksi cabai merahdi Desa Trimulyo Kecamatan Tegineneng Kabupaten Pesawaran.

\section{METODE PENELITIAN}

Metode penelitian yang digunakan adalah metode survei.Penelitian ini dilaksanakan di Desa Trimulyo Kecamatan Tegineneng Kabupaten Pesawaran.Pemilihan lokasi penelitian dilakukan secara sengaja (purposive) dengan pertimbangan bahwa desa tersebut merupakan salah satu sentra penghasil cabai merah di Provinsi Lampung.Populasi pada penelitian ini adalah petani cabai merah di Desa Trimulyo yang semuanya tergabung dalam kelompok tani dengan populasinya sebesar 171 orang.

Pengambilan sampel dilakukan dengan metode (Simple Random Sampling) dengan cara diundi. Penentuan perhitungan sampel mengacu pada Isaac dan Michael (1981) dalam Sugiarto (2003) dengan rumus:

$\mathrm{n}=\frac{\mathrm{NZ}^{2} \mathrm{~S}^{2}}{\mathrm{Nd}^{2}+\mathrm{Z}^{2} \mathrm{~S}^{2}}$

Keterangan:

$\mathrm{n}$ = Jumlah sampel

$\mathrm{N}=$ Jumlah populasi

$\mathrm{Z}=$ Derajat kepercayaan $(90 \%=1,645)$

$\mathrm{S}^{2}=$ Varian sampel $(5 \%=0,05)$

$\mathrm{d}=$ Derajat penyimpang $(5 \%=0,05)$

Berdasarkan perhitungan tersebut diperoleh jumlah sampel petani cabai merah sebesar 60 petani.Penentuan alokasi proporsi sampel petani cabai merah tiap kelompok di Desa Trimulyo menggunakan rumus:

$\mathrm{n}_{\mathrm{i}}=\frac{\mathrm{N}_{\mathrm{i}}}{\mathrm{N}} \times \mathrm{n}$

Keterangan: $\mathrm{n}_{1}=$ Jumlah sampel petani cabai merah di setiap kelompok

$\mathrm{N}_{1}=$ Jumlah petani cabai merah di setiap kelompok

$\mathrm{N}=$ Jumlah keseluruhan populasi petani

$\mathrm{n}=$ Jumlah keseluruhan sampel petani

Berdasarkan perhitungan dengan menggunakan rumus proporsi sampel, maka diperoleh sampel dari Kelompok Tani Sumber Makmur sebanyak 10 petani, Subur sebanyak 8 petani, Tani Makmur II sebanyak 8 petani, Bina Sejahtera sebanyak 10 petani, Sido Rukun sebanyak 8 petani, Tani Makmur sebanyak 9 petani, dan Mitra Tani sebanyak 7 petani.

Data yang digunakan adalah data primer diperoleh melalui wawancara langsung dengan menggunakan kuesioner atau daftar pertanyaan. Selain itu digunakan data sekunder diperoleh dari Badan Pusat Statistik, Kantor Kecamatan, Dinas Petanian, BP3K Kecamatan Tegineneng dan instansi lainnya.Metode analisis yang digunakan adalah metode analisis deskriptif kualitatif dan analisis deskriptif kuantitatif.

\section{Analisis Pendapatan Usahatani Cabai Merah}

Menurut Putra, Zakaria, dan Kasymir (2017), pendapatan diperoleh dengan cara menghitung selisih antara penerimaan dan biaya total produksi yang dikeluarkan. Penerimaan diperoleh dari adanya penjualan hasil panen.Biaya adalah penjumlahan dari biaya tunai dengan biaya tidak tunai.Pendapatan usahatani dapat dirumuskan sebagai berikut:

$\pi=\mathrm{TR}-\mathrm{TC}$

Keterangan:

$\pi \quad=$ Pendapatan usahatani (Rp)

$\mathrm{TR}=$ Total penerimaan $(\mathrm{Rp})$

$\mathrm{TC}=$ Total biaya $(\mathrm{Rp})$

Analisis efisiensi menggunakan rasio $\mathrm{R} / \mathrm{C}$ atas biaya tunai dan $\mathrm{R} / \mathrm{C}$ atas biaya total. Rumus $\mathrm{R} / \mathrm{C}$ secara matematis dapat dituliskan sebagai berikut:

$\mathrm{R} / \mathrm{C}=\frac{\mathrm{TR}}{\mathrm{TC}}$

Keterangan:

$\mathrm{R} / \mathrm{C}=$ Nisbah penerimaan dan biaya

$\mathrm{TR}=$ Penerimaan total

$\mathrm{TC}=$ Biaya total $(\mathrm{Rp})$ 
Jika $\mathrm{R} / \mathrm{C}>1$, maka usahatani yang dilakukan menguntungkandan jika $\mathrm{R} / \mathrm{C}<1$, maka usahatani yang dilakukan merugikan.

\section{Analisis Faktor-faktor yang Mempengaruhi Produksi Cabai Merah}

Analisis yang digunakan adalah analisis fungsi produksi Cobb-Douglas untuk mengetahui besarnya pengaruh dari variabel-variabel input dalam menghasilkan output cabai merah. Menurut Noer, Zakaria, dan Muniarti (2017), penggunaan faktor-faktor produksi yang bervariasi mengakibatkan bervariasinya tingkat produksi yang dihasilkan dengan model fungsi produksi yang digunakan untuk menganalisis usaha cabai merah dalam bentuk logaritma natural (ln) sebagai berikut:

$$
\begin{aligned}
& \ln Y=L n \alpha+\beta_{1} \ln X_{1}+\beta_{2} \ln X_{2}+\beta_{3} \ln X_{3}+\beta_{4} \\
& \ln X_{4}+\beta_{5} \ln X_{5}+\beta_{6} \ln X_{6}+\beta_{7} \ln X_{7}+\beta_{8} \\
& \ln \mathrm{X}_{8}+\mathrm{U}
\end{aligned}
$$

\section{Keterangan:}

$\mathrm{Y}=$ Produksi cabai merah yang dihasilkan $(\mathrm{kg})$

$\alpha=$ Intersep regresi

$\beta=$ Koefisien regresi sekaligus elastisitasproduksi input

$\mathrm{X}_{1}=$ Luas lahan (ha)

$\mathrm{X}_{2}=$ Benih $(\mathrm{kg})$

$\mathrm{X}_{3}=$ Pupuk $\mathrm{KNO}_{3}(\mathrm{~kg})$

$\mathrm{X}_{4}=$ Pupuk kandang $(\mathrm{kg})$

$\mathrm{X}_{5}=$ PupukNPK mutiara $(\mathrm{kg})$

$\mathrm{X}_{6}=$ Pupuk phonska $(\mathrm{kg})$

$\mathrm{X}_{7}=$ Pestisida $(\mathrm{Gba})$

$\mathrm{X}_{8}=$ Tenaga kerja (HOK)

$\mathrm{U}=$ Kesalahan (Disturbance Error)

Metode estimasi yang digunakan adalah Ordinary Least Square (OLS), sebelum diregresikan harus memenuhi kaidah uji asumsi klasik yaitu uji multikolinearitas dengan melihat nilai VIF $<10$ sehingga model tersebut bebas multikoliniearitas, kemudian dilanjutkan uji white dengan membandingkan nilai probabilitas chi squaredengan taraf signifikansi $(\alpha)$ adalah 0,05 . Jika prob chi square $<\alpha$ dapat disimpulkan didalam model regresi ada masalah heteroskedastisitas.

Pengukuran uji hipotesisantara lainkoefisien determinasi $\left(\mathrm{R}^{2}\right)$ antara nol dan satu, kemudian uji F-hitung dengan taraf signifikansi $(\alpha)$ yang digunakan adalah 0,05 . Kriteria pengambilan keputusan ditentukan jika nilai signifikansi $>\alpha$, maka terima $\mathrm{H}_{0}$ artinya variabel independen
$\left(\mathrm{X}_{1}, \ldots, \ldots, \quad \mathrm{X}_{8}\right)$ secara bersama-sama tidak berpengaruh nyata terhadap variabel dependen selanjutnya jika nilai signifikansi $<\alpha$, maka tolak artinya variabel independen secara bersama-sama berpengaruh nyata terhadap variabel dependen.

Selanjutnya uji t-hitung dengan taraf signifikansi $(\alpha)$ yang digunakan adalah 0,05. Kriteria pengambilan keputusan ditentukan jika nilai $\mathrm{H}_{0}$ signifikansi $>\alpha$, maka terima $\mathrm{H}_{0}$ artinya variabel independen $\left(\mathrm{X}_{1}, \ldots, \ldots, \mathrm{X}_{8}\right)$ tidak berpengaruh nyata terhadap variabel dependen selanjutnya jika nilai signifikansi $<\alpha$, maka tolak $\mathrm{H}_{0}$ artinya variabel independen berpengaruh nyata terhadap variabel dependen.

\section{HASIL DAN PEMBAHASAN}

\section{Keadaan Umum Responden}

Umur petani cabai merahDesa Trimulyo Kecamatan Tegineneng Kabupaten Pesawaran berkisar antara 27-65 tahun dengan rata-rata 50 tahun.Hal ini menunjukkan bahwa petani cabai merah di daerah penelitian berusia produktif (Mantra 2004).Begitu pula dengan luas lahan yang dimiliki oleh petani responden berkisar antara 0,25-1 ha dengan rata-rata luas lahan 0,41 ha.Ratarata penggunaan benih dan pupuk di Desa Trimulyo Kecamatan Tegineneng Kabupaten Pesawaran disajikan pada Tabel 1.

Berdasarkan rata-rata penggunaan benih dan pupuk oleh petani responden, diketahui bahwa rata-rata penggunaan benih dan pupuk NPK mutiara per hektar pada usahatani cabai merah belum sesuai dengan anjuran.Penggunaan benih dan pupuk yang tidak sesuai anjuran disebabkan oleh harga yang mahal dan terbatasnya persediaan pupuk, sehingga berakibat pada produksi yang tidak maksimal.

Tabel 1. Rata-rata penggunaan benih dan pupuk petani responden di Desa Trimulyo Kecamatan Tegineneng Kabupaten Pesawaran tahun 2019

\begin{tabular}{lcr}
\hline $\begin{array}{c}\text { Jenis benih dan } \\
\text { pupuk }\end{array}$ & $\begin{array}{c}\text { Penggunaan per } \\
\text { ha }\end{array}$ & Anjuran per ha* \\
\hline Benih Lolay (gr) & 123,17 & $150-300$ \\
$\mathrm{KNO}_{3}(\mathrm{~kg})$ & 232,72 & $150-200$ \\
Kandang (kg) & $3.089,43$ & 2.000 \\
NPK Mutiara (kg) & 242,07 & $280-320$ \\
Phonska (kg) & 402,44 & $200-300$ \\
${ }^{*}$ Sumber: Litbang Pertanian $(2013)$ &
\end{tabular}


Penggunaan pestisida dilakukan oleh petani dalam usaha pengendalian terhadap organisme pengganggu berupa hama dan penyakit.Pengendalian hama dan penyakit umumnya dilakukan oleh petani dengan cara mekanik yaitu dengan cara menjaga kebersihan ladang, pengaritan rumput, gulma dan sebagainya, sedangkan pengendalian lainnya yaitu dengan cara kimia dengan menggunakan pestisida, insektisida dan sebagainya.

Penggunan pestisida ini dipengaruhi oleh keinginan petani, serangan hama dan penyakit tanaman. Penggunaan pestisida tersebut sudah disesuaikan dengan keadaan atau kondisi tanaman.Pada dasarnya, penggunaan pestisida dimaksudkan untuk mempermudah pekerjaan petani, khususnya dalam kegiatan pemberantasan gulma dan hama penyakit, sehingga waktu yang digunakan lebih cepat dibandingkan dengan cara mekanik.Penerapan pengaplikasian pestisida sangat ditentukan oleh latar belakang dari sumber daya manusianya seperti pendidikan, pengetahuan, dan pengalaman.Frekuensi penyemprotan dalam satu musim tanam antara 5-12 kali.Jenis pestisida yang digunakan oleh petani cabai merah disajikan pada Tabel 2.

Jumlah pestisida yang digunakan oleh petani cabai merah beragam, tergantung pada intensitas serangan hama dan penyakit. Dosis yang digunakan petani berpedoman pada anjuran penggunaan yang terdapat pada kemasan pestisida tersebut.Penggunaan pestisida jenis bionasalebih banyak digunakan dibandingkan jenis pestisida lainnya. Hal ini disebabkan adanya keunggulan dari penggunaan bionasayaitu dapat mengendalikan gulma tuntas sampai ke akarakarnya, bersifat tidak menguap sehingga tidak merusak tanaman, sudah terkandung bahan perekat dan perata sehingga aman jika tiba-tiba hujan dapat dicampur dengan pestisida lainnya dan harga jualnya cukup terjangkau.

Tabel 2. Rata-rata penggunaan pestisida oleh responden petani cabai merah di Desa Trimulyo tahun 2019

\begin{tabular}{lrc}
\hline Jenis Pestisida & $\begin{array}{r}\text { Penggunaan per } \\
\text { ha (Gba) }\end{array}$ & $\begin{array}{r}\text { Anjuran per hektar } \\
\text { (Gba) }\end{array}$ \\
\hline Demolish & 19,08 & 40,50 \\
Atonik & 3,27 & 6,50 \\
Antrakol & 2,40 & 3,00 \\
Bionasa & 691,20 & 720,00 \\
Curacron & 375,83 & 500,00 \\
Winder & 52,50 & 100,00 \\
Regent & 51,25 & 100,00 \\
Promojos & 160,00 & 185,00 \\
\hline
\end{tabular}

Tenaga kerja yang digunakan terdiri dari tenaga kerja dalam keluarga dan tenaga kerja luar keluarga, baik pria maupun wanita yang diukur setara dengan Hari Orang Kerja (HOK).Penyetaraan dilakukan berdasarkan upah tenaga kerja pria dan wanita di lokasi penelitian, yaitu rata-rata Rp60.000/hari.

Jenis pekerjaan yang memanfaatkan tenaga kerja baik dalam keluarga maupun luar keluarga meliputi pengolahan tanah 1 dengan memanfaatkan tenaga mesin, pengolahan tanah 2 mulai memanfaatkan tenaga manusia, penyemaian, penanaman, pemupukan 1-3, penyiangan 1-3, penyulaman, penyiraman $1-3$, pengendalian hama dan penyakit 5-12, serta panen 1-16.

Di lokasi penelitian didapatkan bahwa tidak adanya sistem pengangkutan hasil panen, melainkan para tengkulak datang langsung ke lahan sekaligus melakukan sistem jual beli antar petani dengan tengkulak tersebut.Sebaran pemakaian tenaga kerja oleh petani cabai merah dalam berusahatani cabai merah di lokasi penelitian dapat dilihat pada Tabel 3 .

Berdasarkan Tabel 3, tenaga kerja luar keluarga lebih besar dibandingkan tenaga kerja dalam keluarga. Hal ini berarti, kebutuhan tenaga kerja luar keluarga memiliki proporsi yang besar sehingga petani harus menyediakan dana tunai yang besar untuk membayar upah kerja dalam satu musim.Pengolahan tanah yang pertama menggunakan mesin dengan upah borongan sebesar Rp1.500.000,00/ha yang setara dengan 25 HOK.Kegiatan penanaman dilakukan dengan sistem gotong royong yang lebih memanfaatkan tenaga kerja dalam keluarga dan kegiatan yang paling banyak menggunakan tenaga kerja luar keluarga adalah panen, sebab panen cabai merah di Desa Trimulyo sebanyak 16 kali panen.

Tabel 3. Rata-rata penggunaan tenaga kerja (HOK) oleh petani responden per usahatani tahun 2019

\begin{tabular}{lcc}
\hline \multirow{2}{*}{ Kegiatan } & \multicolumn{2}{c}{ TK per ha } \\
\cline { 2 - 3 } & TKDK $(\mathrm{HOK})$ & TKLK $(\mathrm{HOK})$ \\
\hline Pengolahan Tanah & 1,61 & 29,44 \\
Penyemaian & 2,39 & 0,66 \\
Penanaman & 10,27 & 4,83 \\
Pemupukan & 4,95 & 0,32 \\
Penyiangan & 6,10 & 0,68 \\
Penyulaman & 2,10 & 0,27 \\
Penyiraman & 1,44 & 0,20 \\
Pengendalian HPT & 13,80 & 1,46 \\
Panen & 35,32 & 88,24 \\
\hline Jumlah & 53,13 & 150,91 \\
\hline
\end{tabular}




\section{Analisis Pendapatan Usahatani Cabai Merah}

Komponen biaya terbesar yang dibayarkan petani untuk usahatani cabai merah adalah untuk tenaga kerja dan pupuk.Berdasarkan Tabel 4, diketahui bahwa rata-rata produksi cabai merah per hektar yang diperoleh petani sebesar 8.733,33 kg dengan harga rata-rata sebesar Rp7.277,77 dan besarnya biaya rata-rata dalam satu kali musim tanam sebesar Rp63.559.172,62 per hektar.

Pendapatan atas biaya tunai yang dikeluarkan dalam usahatani cabai merah adalah Rp34.416.181,43 per hektar dan untuk pendapatan atas biaya diperhitungkan adalah sebesar Rp24.520.886,39 per hektar dengan nisbah penerimaan terhadap biaya tunai ( $\mathrm{R} / \mathrm{C}$ ratio) usahatani cabai merah per hektar sebesar 2,18 yang berarti bahwa setiap Rp1,00 biaya tunai yang akan dikeluarkan petani dapat menghasilkan penerimaan sebesar Rp2,18.R/C atas biaya total sebesar 1,63 yang berarti bahwa biaya total yang dikeluarkan petani dapat menghasilkan penerimaan sebesar Rp1,63 dengan keuntungan sebesar $\mathrm{Rp} 1,63$. Berdasarkan nilai $\mathrm{R} / \mathrm{C}$ rasio biaya total dapat disimpulkan bahwa usahatani cabai merah yang dilakukan menguntungkan.

Penelitian ini sejalan dengan penelitian Nisa, Haryono, dan Murniati (2018), bahwa usahatani cabai merah adalah usahatani yang menguntungkan. Nilai pendapatan yang diperoleh yakniRp91.519.527,08. Selain itu, dari hasil penelitian Chonani, Prasmatiwi, dan Santoso (2014), menyimpulkan bahwa usahatani cabai merah adalah usahatani yang menguntungkan dengan nilai pendapatandari usahatani cabai merah Rp56.202.114,24. Perbedaan pendapatan terhadap penelitian terdahulu terletak pada jumlah produksi dan harga cabai merah.Jumlah produksi yang lebih tinggi salah satunya dikarenakan penggunaan varietas cabai merah unggul.

Tabel 4. Analisis penerimaan, biaya, dan pendapatan usahatani cabai merah di Desa Trimulyo Kecamatan Tegineneng Kabupaten Pesawaran tahun 2019

\begin{tabular}{|c|c|c|c|c|c|}
\hline \multirow{3}{*}{ No } & \multirow{3}{*}{ Uraian } & \multirow{3}{*}{ Satuan } & \multicolumn{3}{|c|}{ Usahatani Cabai Merah } \\
\hline & & & \multicolumn{3}{|c|}{ Per 1 ha } \\
\hline & & & Jumlah & Harga (Rp) & Nilai (Rp) \\
\hline \multirow[t]{2}{*}{1.} & Penerimaan & & & & \\
\hline & Produksi Cabai Merah & $\mathrm{Kg}$ & $8.733,33$ & $7.277,77$ & $63.559 .172,62$ \\
\hline \multirow[t]{19}{*}{2.} & Biaya Produksi & & & & \\
\hline & I. Biaya Tunai & & & & \\
\hline & Benih & $\mathrm{Kg}$ & 123,17 & $13.000,00$ & $1.601 .219,51$ \\
\hline & Pupuk $\mathrm{KNO}_{3}$ & $\mathrm{Kg}$ & 232,72 & $19.116,67$ & $4.448 .899,05$ \\
\hline & Pupuk Kandang & $\mathrm{Kg}$ & $3.089,43$ & $1.158,33$ & $3.578 .590,79$ \\
\hline & Pupuk Mutiara & $\mathrm{Kg}$ & 242,07 & $10.166,67$ & $2.461 .077,24$ \\
\hline & Pupuk Phonska & $\mathrm{Kg}$ & 402,44 & $2.300,00$ & $925.609,76$ \\
\hline & Pestisida & $\mathrm{Rp}$ & & & $2.169 .695,12$ \\
\hline & Mulsa & $\mathrm{Rp}$ & & & $4.410 .569,11$ \\
\hline & TK Luar Keluarga & HOK & 150,91 & $60.000,00$ & $9.054 .878,05$ \\
\hline & Pajak & $(\mathrm{Rp} / \mathrm{MT})$ & & & $18.197,83$ \\
\hline & Sewa Lahan & $(\mathrm{Rp} / \mathrm{MT})$ & & & $474.254,74$ \\
\hline & Total Biaya Tunai & (Rp/MT) & & & 29.142.991,19 \\
\hline & II. Biaya Diperhitungkan & & & & \\
\hline & TK Dalam Keluarga & HOK & 53,13 & $60.000,00$ & $3.187 .804,88$ \\
\hline & Penyusutan Alat & (Rp/MT) & & & $542.178,51$ \\
\hline & Sewa Lahan (Milik) & $(\mathrm{Rp} / \mathrm{MT})$ & & & $6.165 .311,65$ \\
\hline & Total Biaya & (Rp/MT) & & & $9.895 .295,04$ \\
\hline & Total Biaya & $(\mathrm{Rp} / \mathrm{MT})$ & & & $39.038 .286,23$ \\
\hline \multirow[t]{3}{*}{3.} & Pendapatan & & & & \\
\hline & $\begin{array}{l}\text { I. Pendapatan Atas Biaya } \\
\text { Tunai }\end{array}$ & $\mathrm{Rp}$ & & & $34.416 .181,43$ \\
\hline & $\begin{array}{l}\text { II. Pendapatan Atas } \\
\text { Biaya Total }\end{array}$ & $\mathrm{Rp}$ & & & $24.520 .886,39$ \\
\hline \multirow[t]{3}{*}{4.} & R/C Ratio & & & & \\
\hline & I. R/C Atas Biaya Tunai & & & & 2,18 \\
\hline & II. R/C Atas Biaya Total & & & & 1,63 \\
\hline
\end{tabular}


Jurnal Ilmu Ilmu Agribisnis: Journal of Agribusiness Science, 9(2), Mei 2021

\section{Faktor-faktor yang Mempengaruhi Produksi Usahatani Cabai Merah}

Faktor-faktor produksi yang diduga berpengaruh nyata terhadap produksi cabai merah terdiri dari delapan variabel, yaitu lahan, benih, pupuk $\mathrm{KNO}_{3}$, pupuk kandang, pupuk mutiara, pupuk phonska, pestisida, dan tenaga kerja.Hasil analisis regresi faktor-faktor yang mempengaruhi produksi usahatani cabai merah di Desa Trimulyo Kecamatan Tegineneng Kabupaten Pesawaran tertera pada Tabel 5. Hasil analisis dapat dilihat bahwa di dalam model regresi tidak terdapat multikolinearitas karena nilai VIF untuk tiap variabel <10.Uji asumsi klasik lainnya yaitu uji heteroskedastisitas. Hasil pengidentifikasian heteroskedastisitas dengan Eviews dapat dilihat dari nilai Prob Obs $R *$ squared $\geq 0,05$, berarti tidak terdapat heteroskedastisitas.

Hasil regresi menunjukkan nilai koefisien determinasi ( $R$-square) sebesar 0,963 dengan kata lain, hal ini menunjukkan bahwa besar persentase variasi produksi cabai merah dapat dijelaskan oleh variasi dari variabel lahan, benih, pupuk $\mathrm{KNO}_{3}$, pupuk kandang, pupuk mutiara, pupuk phonska, pestisida, dan tenaga kerja sebesar 96,3\% sedangkan sisanya sebesar $3,7 \%$ dijelaskan oleh variabel lain yang tidak dimasukkan ke dalam model. Penelitian ini juga menunjukkan F-hitung $>$ F-tabel untuk analisis produksi cabai merah sebesar $(64,24>2,19)$ dengan tingkat kepercayaan 99 persen. Hasil tersebut menunjukkan bahwa $\mathrm{H}_{0}$ ditolak yang berarti secara bersama-sama variabel bebas yaitu lahan, benih, pupuk $\mathrm{KNO}_{3}$, pupuk kandang, pupuk mutiara, pupuk phonska, pestisida, dan tenaga kerja berpengaruh nyata terhadap produksi usahatani cabai merah di Desa Trimulyo Kecamatan Tegineneng Kabupaten Pesawaran.

Pengaruh faktor produksi terhadap produksi cabai merah dijelaskan sebagai berikut:

\section{Luas lahan $\left(\mathrm{X}_{1}\right)$}

Lahan $\left(\mathrm{X}_{1}\right)$ berpengaruh nyata terhadap produksi cabai merah pada tingkat kepercayaan 99 persen.Nilai koefisien regresi yang diperoleh adalah 0,573 artinya semakin luas lahan yang digunakan, maka akan semakin tinggi produksi cabai merah yang dihasilkan. Hasil penelitian ini sejalan dengan penelitian Sarina, Silamat,dan Puspitasari (2015), menyatakan bahwa semakin luas lahan yang dimiliki petani cabai merah, maka akan meningkatkan hasil produksi cabai merah.
Tabel 5. Hasil analisis faktor-faktor yang mempengaruhi produksi usahatani cabai merah di Desa Trimulyo Kecamatan Tegineneng Kabupaten Pesawaran tahun 2019

\begin{tabular}{|c|c|c|c|c|}
\hline Variabel & $\begin{array}{c}\text { Koef. } \\
\text { Regresi }\end{array}$ & $\begin{array}{c}\mathrm{t}- \\
\text { hitung }\end{array}$ & Sig & VIF \\
\hline Konstanta & $6,527 * * *$ & 13,334 & 0,000 & \\
\hline Lahan & $0,573 * * *$ & 8,076 & 0,000 & 8,662 \\
\hline Benih & $0,316 * * *$ & 3,973 & 0,000 & 7,400 \\
\hline Pupuk $\mathrm{KNO}_{3}$ & $0,101 * *$ & 2,191 & 0,033 & 2,359 \\
\hline Ppk Kandang & 0,003 & 0,070 & 0,944 & 2,421 \\
\hline Pupuk Mutiara & 0,052 & 1,338 & 0,187 & 2,852 \\
\hline Ppk Phonska & $-0,024$ & $-0,649$ & 0,519 & 3,585 \\
\hline Pestisida & $0,113 * * *$ & 3,438 & 0,001 & 1,618 \\
\hline Tenaga Kerja & $-0,108$ & $-1,381$ & 0,173 & 6,128 \\
\hline \multicolumn{2}{|l|}{$R$-squared } & 0,963 & & \\
\hline \multicolumn{2}{|c|}{ Adjusted R-squared } & 0,957 & & \\
\hline \multicolumn{2}{|c|}{ Prob $O b s * R$-squared } & 0,380 & & \\
\hline \multicolumn{2}{|c|}{ F-statistic } & 64,24 & 0,000 & \\
\hline
\end{tabular}
tingkat kepercayaan $99 \%$

\section{Benih $\left(X_{2}\right)$}

Benih $\left(\mathrm{X}_{2}\right)$ berpengaruh nyata terhadap produksi cabai merah pada tingkat kepercayaan 99 persen.Nilai koefisien regresi yang diperoleh adalah positif sebesar 0,316 artinya semakin tinggi jumlah benih yang digunakan, maka akan semakin tinggi produksi cabai merah yang dihasilkan. Semakin banyak penggunaan benih (sesuai dengan rekomendasi) akan meningkatkan produksi. Dimana jika penambahan sebesar satu satuan benih akan diikuti dengan kenaikan produksi. Hasil penelitian ini sejalan dengan penelitian Pranata dan Damayanti(2016) mengenai faktor-faktor yang mempengaruhi produksi cabai merah di Desa Bolupountu Jaya Kecamatan Sigi Kabupaten Sigi.

\section{Pupuk $\mathrm{KNO}_{3}\left(\mathrm{X}_{3}\right)$}

Pupuk $\mathrm{KNO}_{3}\left(\mathrm{X}_{3}\right)$ berpengaruh nyata terhadap produksi cabai merah pada tingkat kepercayaan 95 persen.Nilai koefisien regresi yang diperoleh adalah positif sebesar 0,101 artinya semakin tinggi jumlah pupuk $\mathrm{KNO}_{3}$ yang digunakan, maka semakin tinggi produksi cabai merah yang dihasilkan.

\section{Pupuk kandang $\left(\mathrm{X}_{4}\right)$}

Pupuk kandang $\left(\mathrm{X}_{4}\right)$ tidak berpengaruh nyata terhadap produksi cabai merah karena tingkat kepercayaan hanya sebesar 5,6 persen. Hasil penelitian ini sejalan dengan penelitian Pranata 
dan Darmayanti (2016) mengenai analisis faktor-faktor yang mempengaruhi cabai merah di Desa Bolupountu Jaya Kecamatan Sigi Kabupaten Sigi, menyatakan bahwa pupuk kandang tidak berpengaruh nyata terhadap hasil produksi cabai merah. Hal ini disebabkan jumlah penggunaan pupuk menurut standar sebesar $800 \mathrm{kw} / \mathrm{ha}$. Berdasarkan keadaan di lapangan menyatakan bahwa pemberian pupuk dengan ditabur memiliki kelemahan yaitu pada saat cuaca terik pupuk akan mudah terbawa air, selain itu memungkinkan pertumbuhan gulma lebih cepat dan kurang tepat sasaran, sehingga menyebabkan pola pertumbuhan cabai merah kurang optimal. Sebaiknya pupuk dilarutkan ke dalam air terlebih dahulu, kemudian pupuk disemprotkan pada lahan tanaman cabai merah.

\section{Pupuk mutiara $\left(\mathrm{X}_{6}\right)$}

Pupuk mutiara $\left(\mathrm{X}_{6}\right)$ tidak berpengaruh nyata terhadap produksi cabai merah karena tingkat kepercayaan hanya sebesar 81,3 persen. Hal ini dikarenakan penggunaan pupuk mutiara yang belum sesuai dengan batas anjuran dalam meningkatkan produksi cabai merah.Penggunaan pupuk tersebut belum memenuhi anjuran penggunaan yang disebabkan oleh harga pupuk tersebut cukup mahal dibandingkan harga pupuk lainnya. Menurut Hardjowigeno (2007) penggunaan pupuk anorganik haruslah seimbang sehingga tanaman lebih sehat dan produksi meningkat.

\section{Pupuk phonska $\left(\mathrm{X}_{7}\right)$}

Pupuk phonska $\left(\mathrm{X}_{7}\right)$ tidak berpengaruh nyata terhadap produksi cabai merah karena tingkat kepercayaan hanya sebesar 48,1 persen.Nilai koefisien bernilai positif.Berdasarkan keadaan di lapangan, petani menyatakan bahwa penggunaan pupuk phonska oleh petani telah melampaui anjuran.Petani cabai merah di daerah tersebut, lebih cenderung membeli pupuk subsidi dalam jumlah yang banyak dan pembelian pupuk lainnya cenderung sedikit.Hal ini terjadi karena harga pupuk subsidi jauh lebih murah dibandingkan harga pupuk non subsidi.

\section{Pestisida $\left(\mathrm{X}_{8}\right)$}

Pestisida $\left(\mathrm{X}_{8}\right)$ berpengaruh nyata terhadap produksi cabai merah pada tingkat kepercayaan 99 persen.Nilai koefisien regresi yang diperoleh adalah positif sebesar 0,113 artinya semakin tinggi pestisida yang digunakan, maka semakin tinggi produksi cabai merah yang dihasilkan.Penggunaan pestisida tersebut sudah disesuaikan dengan keadaan atau kondisi tanaman.Hasil penelitian ini sejalan dengan penelitian Andayani (2016), bahwa pestisida berpengaruh nyata terhadap produksi cabai merah dan penerapan pengaplikasian sangat ditentukan oleh latar belakang sumber daya manusianya.

\section{Tenaga kerja $\left(\mathrm{X}_{5}\right)$}

Tenaga Kerja $\left(\mathrm{X}_{5}\right)$ tidak berpengaruh nyata terhadap produksi cabai merah karena tingkat kepercayaan hanya sebesar 82,7 persen. Nilai koefisien bernilai negatif.Berdasarkan hasil wawancara di lapangan, beberapa petani responden ada yang menggunakan tenaga kerja lebih sedikit untuk menekan biaya budidaya dan rata-rata luas lahan petani responden tergolong luas lahan berskala kecil yang berarti tidak perlu adanya penambahan tenaga kerja, sebab dapat dikerjakan tenaga kerja dalam keluarga sendiri.Oleh karena itu berapapun jumlah tenaga kerja tidak mempengaruhi produksi cabai merah.

Hasil penelitian ini sejalan dengan penelitian Sarina, Silamat,dan Puspitasari (2015) mengenai analisis faktor-faktor yang mempengaruhi produksi cabai merah di Desa Kampung Melayu Kecamatan Bermani Ulu Kabupaten Rejang Lebong menyatakan bahwa tenaga kerja tidak berpengaruh nyata terhadap produksi cabai merah karena banyak atau sedikitnya jumlah tenaga kerja yang dipekerjakan pada lahan pertanian tidak menjadikan patokan untuk meningkatkan produksi cabai merah yang dihasilkan, melainkan mengutamakan keahlian, dan keuletan para tenaga kerja.Bisa saja lahan yang luas dikerjakan oleh sedikit tenaga kerja tapi mereka memiliki kemampuan yang lebih sehingga dapat mengefesiensikan waktu produksi serta dapat pula meningkatkan hasil produksi cabai merah.

Menurut Berliantara, Zakaria, dan Lestari (2016), umur petani juga sangat berperan dalam pelaksanaan usahatani cabai merah. Umur yang semakin lanjut akan mempengaruhi tingkat produktivitas petani yang semakin berkurang.Tenaga kerja yang terampil akan mempermudah dalam menerapkan teknologi tepat guna sesuai anjuran. Kondisi kelompok umur petani responden Desa Trimulyo masih 
didominasi oleh kelompok umur produktif yaitu sekitar umur 15-64 tahun.Namun, kurang terampil dalam menerapkan teknologi tepat guna sesuai dengan anjuran.

\section{KESIMPULAN}

Usahatani cabai merah di Desa Trimulyo Kecamatan Tegineneng Kabupaten Pesawaran merupakan usahatani yang menguntungkan dengan pendapatan atas biaya tunai sebesar Rp34.416.181,43 dengan nilai $\mathrm{R} / \mathrm{C}$ atas biaya tunai sebesar 2,18 dan pendapatan atas biaya total sebesar Rp24.520.886,39 dengan nilai R/C atas biaya total sebesar 1,63 serta faktor-faktor yang mempengaruhi produksi cabai merah adalah luas lahan, benih, pupuk $\mathrm{KNO}_{3}$ dan pestisida.

\section{DAFTAR PUSTAKA}

Andayani SA. 2016. Faktor-faktor yang mempengaruhi produksi cabai merah. Mimbar Agribisnis, $\quad$ 1(3): 261-267. https://www.neliti.com/id/publications/25927 2/faktor-yang-mempengaruhi-produksi-cabaimerah\&ved. [25 April 2020].

BPS [Badan Pusat Statistik] Lampung. 2018. Provinsi Lampung dalam Angka 2018. https://lampung.bps.go.id. [3 November 2018].

Berliantara, Zakaria WA, dan Lestari DAH. 2016. Analisis efisiensi produksi dan keuntungan usahatani tomat dataran rendah di Kabupaten Lampung Selatan. Jurnal Ilmu Ilmu $\begin{array}{llll}\text { Agribisnis, } & 4 & \text { (4): } & 342-350 .\end{array}$ http://jurnal.fp.unila.ac.id/index.php/JIIA/sear $\mathrm{ch} /$ search?simpleQuery=Berliantara\&searchFi eld=query.[8 Januari 2019].

Chonani SH, Prasmatiwi FE, dan Santoso H. 2014.Efisiensi produksi dan pendapatan usahatani cabai merah di Kecamatan Metro Kibang Kabupaten Lampung Timur. Jurnal Ilmu Ilmu Agribisnis, 2(2): 102-102. http://jurnal.fp.unila.ac.id/index.php/JIIA/sear $\mathrm{ch} /$ search?simpleQuery=Siti\&searchField=qu ery. [6 Januari 2019].

Direktorat Perlindungan Hortikultura Lampung. 2018. Sentra Produksi Cabai Merah. http://ditlin.hotikultura.pertanian.go.id. Desember 2018].

Hardjowigeno S. 2007. Ilmu Tanah Cetakan Keenam. Akademika Pressindo. Jakarta.

Litbang Pertanian. 2013. Pupuk dan Pemupukan pada Budidaya Cabai. https//hortikultura.litbang.pertanian.go.id. [5 Oktober 2019].
Mantra BI. 2004. Filsafat Penelitian dan Metode Penelitian Sosial. Pustaka Belajar. Yogyakarta.

Moekasan TN, Prabaningrum L, dan Yoga WA. 2014. Panduan Praktis Budidaya Cabai Merah Berdasarkan Konsepsi Pengendalian Hama Terpadu (PHT). PT. Penebar Swadaya. Jakarta.

Nisa UK, Haryono D, dan Murniati K. 2018. Pendapatan usahatani cabai merah di Kecamatan Kalianda Kabupaten Lampung Selatan. Jurnal Ilmu Ilmu Agribisnis, 6(2):153-154.

http://jurnal.fp.unila.ac.id/index.php/JIIA/sear $\mathrm{ch} /$ search?simpleQuery=Ulpah\&searchField= query. [8 Januari 2019].

Noer SR, Zakaria WA, dan Murniati K. 2017. Analisis efisiensi produksi usahatani padi ladang di Kecamatan Sidomulyo Kabupaten Lampung Selatan. Jurnal Ilmu Ilmu Agribisnis, 6(1):18-24. http://jurnal.fp.unila.ac.id/index.php/JIIA/sear $\mathrm{ch} /$ search? simpleQuery=Suci\&searchField $=\mathrm{q}$ uery. [6 Januari 2019].

Pranata dan Damayanti. 2016. Faktor-faktor yang mempengaruhi produksi cabai merah keriting di Desa Bolupountu Jaya Kecamatan Sigi Kabupaten Sigi. Jurnal Agroland, 23(1):1119.

http://jurnal.untad.ac.id/jurnal/index.php/AGR OLAND/viewFile/8108/6425.[25April 2020].

Putra RK., Zakaria WA, dan Kasymir E. 2017. Analisis keuntungan dan harapan keuntungan cabai merah pada klaster cabai di Kabupaten Lampung Selatan. Jurnal Ilmu Ilmu Agribisnis, $\quad$ 5(2):147-148. http://jurnal.fp.unila.ac.id/index.php/JIIA/sear $\mathrm{ch} /$ search?simpleQuery=Rachmat\&searchFiel $\mathrm{d}=$ query. [8 Januari 2019].

Sarina, Silamat E, dan Puspitasari D. Analisis faktor-faktor yang mempengaruhi produksi cabai merah di Desa Kampung Melayu Kecamatan Bermani Ulu Kabupaten Rejang Lebong. Jurnal Agroqua, 13(2):57-67. https://journals.unihaz.ac.id/index.php/agroqu a/article/download/16/8/\&ved.[11 Febuari 2020].

Sugiarto. 2003.Teknik Sampling. PT. Gramedia Pustaka Utama. Jakarta.

Supriadi B dan Roedjinandari N. 2017. Perencanaan dan Pengembangan Pariwisata. Universitas Negeri Malang. Malang.

Tim Bina Karya Tani. 2008. Pedoman Bertanam Cabai. Yrama Widya. Makasar. 